\title{
FAKTOR-FAKTOR YANG MEMPENGARUHI KEPUTUSAN PEMBELIAN RUMAH DAN APARTEMEN KELAS MENENGAH BAWAH DI SURABAYA, GRESIK, DAN SIDOARJO
}

\author{
Adi S. C. Wijaya ${ }^{1}$, Timoticin Kwanda², Jani Rahardjo ${ }^{3}$
}

\begin{abstract}
ABSTRAK: Konsumen properti kelas menengah bawah di wilayah Surabaya dan sekitarnya dapat dihadapkan dengan dua pilihan properti yang berbeda. Dengan harga yang relatif sama konsumen bisa membeli apartemen menengah bawah di Surabaya atau rumah menengah bawah di Gresik atau Sidoarjo (pinggiran kota Surabaya). Ada 3 faktor utama yang mempengaruhi keputusan pembelian properti yaitu faktor konsumen, produk, dan pengembang. Keputusan pembelian untuk salah satu jenis properti diatas akan dijelaskan dari ketiga faktor tersebut.Penelitian ini bertujuan untuk mencari faktor-faktor yang paling membedakan pertimbangan keputusan pembelian konsumen rumah menengah bawah di Gresik atau Sidoarjo dengan konsumen apartemen menengah bawah di Surabaya. Dengan analisa regresi logistik dan deskriptif mean, faktor-faktor tersebut dapat dianalisa sehingga dapat diketahui faktor/indikator mana yang paling mempengaruhi keputusan pembelian masing-masing jenis properti. Hasil dari penelitian ini melalui regresi logistik menunjukkan bahwa ada dua faktor yang membedakan keputusan pembelian kedua jenis properti tersebut secara signifikan, yaitu faktor pendidikan konsumen dan faktor pengembang. Dengan analisa mean juga didapatkan beberapa perbedaan karakter konsumen dan persepsi terhadap tingkat kepentingan faktor produk maupun pengembang.
\end{abstract}

Kata kunci : rumah, apartemen, menengah bawah, keputusan pembelian, properti, pengembang

\begin{abstract}
Middle-low property consumers in Surabaya and its surroundings are offered with two different choices. At the same price range, consumers could either buy a middle-low class apartment in Surabaya or alternatively a middle-low class house in Gresik or Sidoarjo. There are three main factors that affect buying decision for a property, which include consumer factor, product factor, and developer factor. Buying decision for a particular type of property can be explained by those factors. This research aims to find the different level of importance in regards to the factors that affect buying decision between a middle-low class apartment in Surabaya or a middle-low class house in Gresik or Sidoarjo. Logistic regression and mean analysis will be utilized to identify the significant differences in the factors affecting buying decision for each type of property. The results of this research, using logistic regression shows that there are two factors that differentiate buying decision significantly, which are consumers' education level and developerfactor. Mean analysis also indicates that between the buyers of those two types of properties, there are some differences in consumers' character and perception regarding the importance level of both product factor and developer factor.
\end{abstract}

Keywords: house, apartment, middle-low, property, buying decision, developer

\footnotetext{
${ }^{1}$ Mahasiswa Program Studi Magister Teknik Sipil Universitas Kristen Petra, adi.scw@gmail.com

${ }^{2}$ Dosen Program Studi Magister Teknik Sipil Universitas Kristen Petra, cornelia@petra.ac.id

${ }^{3}$ Dosen Program Studi Magister Teknik Sipil Universitas Kristen Petra, jani@petra.ac.id
} 


\section{PENDAHULUAN}

Tren lonjakan pembangunan rumah dan apartemen kelas menengah bawah terjadi beberapa tahun terakhir di kota-kota besar Jawa Timur (Surendra 2014). Sejumlah penelitian (Faqih, Putri, dan Setijanti 2016) telah mempelajari perilaku konsumen apartemen di kota Surabaya dan beberapa penulis lain fokus meneliti perilaku konsumen rumah tinggal di pinggiran Surabaya seperti di wilayah Sidoarjo dan Gresik (Kwanda, Rahardjo, dan Wibowo, 2003). Penelitian ini akan meneliti dan membandingkan faktor-faktor yang mempengaruhi keputusan pembelian apartemen kelas menengah bawah di kota Surabaya dengan rumah kelas menengah bawah di wilayah Gresik dan Sidoarjo karena pada saat memutuskan untuk membeli, kedua jenis properti di atas memiliki kaitan satu sama lain. Faktor-faktor yang akan dianalisa terdiri dari 3 faktor utama, yaitu faktor konsumen, produk, dan pengembang.

\section{LANDASAN TEORI}

\subsection{Faktor Konsumen}

Menurut Salama (2006) dan Listyorini (2012) faktor gaya hidup adalah salah satu faktor yang sangat mempengaruhi keputusan pelanggan dalam membeli rumah. Pada penelitian yang dilakukan oleh Salama (2006) ditemukan bahwa gaya hidup manusia mempengaruhi pemilihan lokasi rumah, penampilan visual rumah, dan tingkat kepuasan. Kesimpulan dari penlitian tersebut juga menuliskan bahwa konsumen dengan penghasilan rendah akan memilih membeli rumah yang melewati taman, dan memilikki batasan-batasan yang jelas. Sedangkan menurut Listyorini (2012) faktor gaya hidup disini meliputi beberapa hal yakni aspek sosial, rumah tangga, kesenangan, dan referensi. Faktor konsumen yang akan diteliti terdiri dari beberapa indikator yaitu usia, pendidikan, etnis, pekerjaan, pendapatan, dan preferensi hiburan.

\subsection{Faktor Produk}

Kwanda, Rahardjo, dan Wibowo (2003) menyatakan bahwa faktor yang paling mempengaruhi kepuasan pelanggan dalam pembelian rumah murah adalah lokasi, kualitas bangunan, kemudian infrastruktur, utilitas dan fasilitas. Sianturi (2006) menambahkan dalam penelitiannya bahwa faktor utama yang mempengaruhi pembelian rumah adalah faktor harga kemudian diikuti oleh faktor lokasi. Gallion dan Eisner (1986) menjabarkan bahwa lokasi perumahan yang baik memiliki ketengan, jauh dari kebisingan maupun pabrik, bebas polusi, dan memiliki akses mudah menuju pelayanan kesehatan, pendidikan dan perdaganan. Widiastuti dan Handayani (2013) menguraikan bahwa permintaan terhadap suatu rumah dipengaruhi oleh fasilitas dan sarana umum. Sedangkan untuk apartemen, Arleflanto (2011) menyatakan bahwa kualitas pelayanan memilikki peran yang lebih dalam menentukan keputusan pembelian. Kualitas pelayanan disini berbicara mengenai tingkat kebersihan lobi utama, kebersihan elevator, kecepatan staff apartemen dalam merespon permohonan penghuni, dan yang terakhir adalah keramahan staff apartemen.

\subsection{Faktor Pengembang}

Cheng dan Cheok (2008) membuktikan bahwa konsumen di Malaysia lebih memilih untuk membeli properti dari pengembang yang namanya sudah tidak asing bagi mereka. Dalam penelitian tersebut terbukti bahwa pengembang yang lebih dikenal konsumen dengan reputasi positif cenderung lebih mengikuti trend, profesional, dan pandai memilih lokasi pengembangan. Dalam penelitian yang dilakukan oleh Katili, Setiawan, dan Nugroho (2016) telah dibuktikan bahwa brand image pengembang properti sangat mempengaruhi keputusan pembelian rumah. Indikator-indikator dalam faktor brand image yang paling mempengaruhi keputusan pembelian adalah kesesuaian janji pengembang, perhatian terhadap pribadi 
pelanggan, komunikasi media periklanan, dan keunggulan estetika (Katili, Setiawan, dan Nugroho, 2016).

\subsection{Rumah Kelas Menengah Bawah}

Menurut Keputusan Menteri Keuangan NO. 393/KMK.04/1996 rumah sederhana memilikki luas bangunan kurang dari $70 \mathrm{~m} 2$ dan luas tanahnya tidak lebih dari $200 \mathrm{~m} 2$, sedangkan berdasarkan Keputusan Menteri Permukiman Dan Prasarana Wilayah No. 242003 rumah kelas bawah (sederhana) adalah rumah yang luasan tanah/bangunannya tidak lebih dari 54 $\mathrm{m} 2 / 36 \mathrm{~m} 2$. Menurut Cushman and Wakefield rumah dengan harga antara 400 hingga 800 juta termasuk kategori menengah bawah sedangkan rumah seharga dibawah 400 juta termasuk kategori kelas bawah (Erawan, 2015). Menurut Bank Rakyat Indonesia (BRI) kategori rumah kelas menengah adalah rumah dengan harga antara 300 hingga 400 juta rupiah (Rahman, 2016). Lalu Bank Indonesia mengategorikan rumah kelas menengah dengan batasan luas bangunan antara 36 hingga $72 \mathrm{~m} 2$ (Ibrahim, 2016). Maka dari itu dengan menggabungkan data dari sumber-sumber diatas, penelitian ini mengategorikan rumah menengah bawah dengan batasan harga tidak lebih dari 500 juta rupiah, luas bangunan antara $36 \mathrm{~m} 2$ hingga $72 \mathrm{~m} 2$ dan luas tanah tidak lebih dari $200 \mathrm{~m} 2$.

\subsection{Apartemen Kelas Menengah Bawah}

Kyle, Baird, dan Spodek (2000) menulis bahwa ada beberapa jenis apartemen high-rise berdasarkan kelasnya, yaitu kelas bawah, menengah, dan atas. Dengan semakin menipisnya jumlah persediaan tanah di perkotaan, maka pengembang dituntut untuk membangun secara vertikal. Meski dibutuhkan biaya perijinan yang jauh lebih mahal dibanding pengembangan landed-houses, penghematan dari biaya lahan dan konstruksi jauh lebih menguntungkan bagi pengembang (Kyle, Baird, dan Spodek, 2000). Menurut Properti Indonesia (2014) apartemen dapat dikategorikan kelas menengah jika harganya 15 hingga 30 juta rupiah per $\mathrm{m} 2$ dan luas unitnya antara 21-53 m2. Binakarya Propertindo Group (Binakarya Jaya Abadi, 2015) menyatakan bahwa apartemen kelas menengah di Indonesia harganya berada di kisaran 300 juta rupiah. Menurut Cushman and Wakefield (Rusyanto, 2016) apartemen dengan harga 15 - 20 juta per $\mathrm{m} 2$ atau seharga 330-440 juta per unit bisa dikategorikan kelas menengah bawah. Dari sumber-sumber tersebut maka batasan untuk penelitian ini adalah harga per unit tidak lebih dari 500 juta rupiah dan luas per unit tidak lebih dari $50 \mathrm{~m} 2$.

\section{METODOLOGI PENELITIAN}

Penelitian ini dilakukan secara kuantitatif dengan cara menyebarkan kuesioner kepada penghuni apartemen kelas menengah bawah di Surabaya dan rumah kelas menengah bawah di Gresik dan Sidoarjo. Populasi sampel adalah orang yang sudah membeli salah satu dari kedua jenis properti tersebut. Penarikan sampel dilakukan dengan pendekatan secara purposive. Pendekatan ini melibatkan pemilihan kelompok subyek yang populasinya didasarkan dengan persyaratan, sifat, ataupun karakter yang sudah diketahui dan ditentukan sebelumnya secara sengaja oleh peneliti karena pertimbangan tertentu. Ukuran sampel dihitung menggunakan metode Bhattacharya (1996) dengan nilai $\square=10 \%$ dan $\mathrm{d}=10 \%$ maka didapatkan 68 sampel. Teknik analisa data dilakukan menggunakan software SPSS dengan beberapa teknik yaitu analisa deskriptif dan mean, uji validitas dan reliabilitas, kemudian regresi logistik.

\section{ANALISA DAN PEMBAHASAN}

\subsection{Gambaran Umum Obyek Penelitian}

Penelitian bertujuan untuk menganalisa faktor-faktor yang mempengaruhi keputusan pembelian konsumen apartemen kelas menengah bawah di kota Surabaya dan rumah kelas 
menengah bawah di wilayah Sidoarjo dan Gresik. Ada 68 sampel yang valid terdiri dari 41 responden rumah kelas menengah bawah di Gresik atau Sidoarjo dan 27 responden apartemen kelas menengah bawah di Surabaya. Penyebaran kuesioner dilakukan dengan cara mendatangi dan menyebarkan kuesioner secara langsung kepada penghuni rumah dan apartemen. Nama perumahan dan apartemen tersebut dapat dilihat pada Tabel 1 dibawah. Ada tiga variabel yang akan diuji pada penelitian ini yaitu faktor konsumen, faktor produk, dan faktor pengembang.

Tabel 1. Nama Apartemen dan Perumahan untuk Objek Penelitian

\begin{tabular}{|l|c|l|}
\hline \multicolumn{3}{|c|}{ Apartemen Menengah Bawah di Surabaya } \\
\hline Nama & Jumlah & Lokasi \\
\hline Gunawangsa Manyar & 7 & Manyar, Surabaya \\
\hline Puncak Kertajaya & 8 & Kertajaya, Surabaya \\
\hline Educity & 5 & Pakuwon City, Surabaya \\
\hline Metropolis & 7 & Tenggilis, Surabaya \\
\hline \multicolumn{2}{|c|}{ Rumah Menengah Bawah di Gresik/Sidoarjo } \\
\hline Nama & Jumlah & Lokasi \\
\hline Oma Indah & 8 & Menganti, Gresik \\
\hline Oma Greenland & 5 & Hulaan, Gresik \\
\hline Graha Naila & 7 & Hulaan, Gresik \\
\hline Green Park Residence & 6 & Gedangan, Sidoarjo \\
\hline Permata Regency & 5 & Tanggulangin, Sidoarjo \\
\hline Jasmine Residence & 10 & Krian, Sidoarjo \\
\hline
\end{tabular}

\subsection{Hasil Uji Validitas Kuesioner}

Uji validitas digunakan untuk mengukur sejauh mana keakuratan, ketepatan, dan kecermatan suatu alat ukur atau indikator dalam menjalankan fungsinya (Azwar, 2007). Penelitian ini menggunakan software IBM SPSS v.24 untuk mengetahui nilai Corrected Item-Total Correlation dan menentukan valid tidaknya indikator-indikator tersebut. Tinggi tidaknya nilai Corrected Item-Total Correlation akan menentukan validitas suatu indikator. Nilai yang akan dihitung tersebut akan dibandingkan dengan standard nilai r-value pada tabel statistic. Pada penelitian ini terdapat 68 sample data atau responden dan nilai $\alpha$ atau tingkat significany yang digunakan adalah $10 \%$ sehingga nilai r-tabel yang akan dijadikan acuan adalah 0.2012. Semua indikitor yang diuji mempunyai nilai Corrected Item-Total Correlation diatas nilai rvalue (0.2012) sehingga indikator-indikator dibawah dinyatakan valid.

\subsection{Hasil Uji Reliabilitas Kuesioner}

Uji reliabilitas bertujuan untuk membuktikan apakah suatu alat ukur dapat digunakan secara konsisten dengan akurat. Sama halnya dengan uji validitas diatas, uji reliabilitas ini juga dijalankan menggunakan software IBM SPSS v.24 untuk menghitung nilai cronbach alpha. Nilai cronbach alpha ini digunakan untuk mengukur apakah variabel-variabel penelitian reliable. Jika nilai tersebut diatas 0.40 maka variabel tersebut dinyatakan reliable. Dari hasil perhitungan nilai conbrach alpha, maka dapat dibuktikan bahwa variabel-variabel yang akan diuji pada penelitian ini layak digunakan sebagai alat ukur yang reliable, konsisten dan akurat.

\section{4 .Hasil Analisis Deskriptif dan Mean}

Pada Tabel 2 dapat dilihat bahwa ada beberapa perbedaan antara konsumen rumah kelas menengah bawah di Gresik atau Sidoarjo dengan konsumen apartemen kelas menengah bawah di Surabaya. Konsumen apartemen cenderung berusia lebih muda, berpendidikan lebih tinggi, dan mayoritas beretnis Tionghoa. Selain itu mayoritas konsumen apartemen kelas menengah bawah di Surabaya berprofesi sebagai pengusaha, berpenghasilan lebih tinggi, dan memiliki hobi kuliner serta nonton bioskop. Konsumen rumah menengah bawah di Gresik atau Sidoarjo mayoritas beretnis Jawa, berprofesi sebagai karyawan, dan memiliki hobi 
kesenian, olahraga, dan membaca. Konsumen apartemen sangat mementingkan faktor lokasi dan paling mengesampingkan faktor kualitas produk dalam memutuskan pembelian. Sedangkan konsumen rumah menengah bawah di Gresik atau Sidoarjo cenderung mengutamakan faktor kualitas produk dan mengesampingkan faktor media periklanan.

Tabel 2. Analisa Lengkap Semua Faktor

\begin{tabular}{|c|c|c|c|c|c|c|}
\hline & & & \multicolumn{2}{|c|}{$\begin{array}{c}\text { Rumah menengah bawah di } \\
\text { Gresik/Sidoarjo }\end{array}$} & \multicolumn{2}{|c|}{$\begin{array}{l}\text { Apartemen menengah bawah di } \\
\text { Surabaya }\end{array}$} \\
\hline & & & $\begin{array}{r}\text { Rata-Rata/frek. } \\
\text { terbanyak }\end{array}$ & Penjelasan & $\begin{array}{r}\text { Rata-Rata/frek. } \\
\text { terbanyak }\end{array}$ & Penjelasan \\
\hline \multirow{6}{*}{$\begin{array}{l}\text { Faktor } \\
\text { Konsumen }\end{array}$} & \multirow{3}{*}{ Identitas } & Usia & 2.83 & Avg. 38 tahun & 2.22 & Avg. 33 tahun \\
\hline & & Pendidikan & $\begin{array}{l}48.80 \% \\
29.30 \%\end{array}$ & $\begin{array}{l}\text { SMA } \\
\text { Sarjana }\end{array}$ & $\begin{array}{l}51.90 \% \\
40.70 \%\end{array}$ & $\begin{array}{l}\text { Sarjana } \\
\text { Pasca-Sarjana }\end{array}$ \\
\hline & & Etnis & Jawa & $78 \%$ etnis Jawa & Tionghoa & $74.10 \%$ \\
\hline & \multirow{2}{*}{$\begin{array}{c}\text { Pekerjaan } \\
\& \\
\text { pendapatan }\end{array}$} & Pekerjaan & $\begin{array}{r}\text { Karyawan dan Self- } \\
\text { employed }\end{array}$ & $\begin{array}{l}(54.7 \%) \text { dan } \\
(24.4 \%)\end{array}$ & $\begin{array}{l}\text { Pengusaha dan } \\
\text { Self-employed }\end{array}$ & $\begin{array}{l}(55.6 \%) \text { dan } \\
(29.6 \%)\end{array}$ \\
\hline & & Pendapatan & 1.83 & $\begin{array}{l}\text { Avg. } 12.47 \\
\text { juta/bulan }\end{array}$ & 2.07 & $\begin{array}{l}\text { Avg. } 15.25 \\
\text { juta/bulan }\end{array}$ \\
\hline & $\begin{array}{l}\text { Preferensi } \\
\text { Hiburan }\end{array}$ & Hobi & $\begin{array}{r}\text { Kesenian, olahraga, } \\
\text { mambaca }\end{array}$ & $\begin{array}{l}(24.4 \%),(22 \%), \\
(19.5 \%)\end{array}$ & $\begin{array}{r}\text { Kuliner dan } \\
\text { nonton bioskop }\end{array}$ & $\begin{array}{l}(33.3 \%) \text { dan } \\
(25.9 \%)\end{array}$ \\
\hline & & & Ranking & Nilai & Ranking & Nilai \\
\hline \multirow{3}{*}{$\begin{array}{l}\text { Faktor } \\
\text { Produk }\end{array}$} & \multicolumn{2}{|c|}{ Lokasi } & 4 & 3.73 & 1 & 4.69 \\
\hline & \multicolumn{2}{|c|}{ Kualitas Produk } & 1 & 4.14 & 6 & 3.87 \\
\hline & \multicolumn{2}{|c|}{ PSU } & 2 & 3.84 & 2 & 4.66 \\
\hline \multirow{4}{*}{$\begin{array}{c}\text { Faktor } \\
\text { Pengembang }\end{array}$} & \multicolumn{2}{|c|}{ Reputasi } & 5 & 3.41 & 4 & 4.39 \\
\hline & \multicolumn{2}{|c|}{ Tren \& Profesionalisme } & 3 & 3.77 & 3 & 4.46 \\
\hline & \multicolumn{2}{|c|}{ Media Periklanan } & 6 & 3.34 & 5 & 4.17 \\
\hline & \multicolumn{2}{|c|}{ Jenis Media Iklan } & $\begin{array}{l}\text { Teman/kerabat/sau } \\
\text { dara; agen properti }\end{array}$ & $\begin{array}{l}(34.1 \%) \\
(24.4 \%)\end{array}$ & $\begin{array}{r}\text { Agen properti; } \\
\text { internet }\end{array}$ & $\begin{array}{l}(44.4 \%) \\
(18.5 \%)\end{array}$ \\
\hline
\end{tabular}

\subsection{Analisa Regresi Logistik}

Analisa regresi logistik digunakan untuk mencari tahu dan menghitung nilai koefisien variabel independen $(X)$ yang mempengaruhi variabel dependen $(Y)$. Dalam penelitian ini akan diuji satu dependent variable $(Y)$ dengan lima independent variables $(X)$. Dari analisa regresi logistik yang dilakukan maka diperoleh persamaan sebagai berikut:

$Y=32.742+0.362 \mathrm{X}_{1}-1.098 \mathrm{X}_{2}+0.652 \mathrm{X}_{3}-2.273 \mathrm{X}_{4}-5.029 \mathrm{X}_{5}$

Pada persamaan diatas variabel $\mathrm{X} 1$ adalah usia, $\mathrm{X} 2$ adalah pendidikan, $\mathrm{X} 3$ adalah pendapatan, $\mathrm{X} 4$ adalah faktor produk, X5 adalah faktor pengembang, dan $\mathrm{Y}$ adalah jenis properti yang dibeli (1: apartemen di Surabaya; 2: rumah di Gresik atau sidoarjo. Namun pada Tabel 3 dibawah dapat dilihat bahwa hanya 2 faktor yang signifikan yaitu X2 (pendidikan) dan X5 (faktor pengembang).

Tabel 3. Pengujian Masing-Masing Koefisien

\begin{tabular}{|l|r|r|r|r|r|r|r|r|}
\hline & \multicolumn{1}{l}{ B } & \multicolumn{1}{l}{ S.E. } & \multicolumn{2}{l}{ Wald } & \multicolumn{1}{l|}{ df } & \multicolumn{2}{l|}{ Sig. } & \multicolumn{2}{l|}{ Exp(B) } & \multicolumn{2}{l|}{$\begin{array}{l}\text { EXP C.I.for } \\
\text { EXP) }\end{array}$} \\
\hline & & & & & & & \multicolumn{1}{l}{ Lower } & Upper \\
\hline Usia (X1) & 0.362 & 0.79 & 0.21 & 1 & 0.647 & 1.436 & 0.305 & 6.76 \\
\hline Pendidikan (X2) & -1.098 & 0.536 & 4.201 & 1 & 0.04 & 0.333 & 0.117 & 0.953 \\
\hline Pendapatan (X3) & 0.652 & 1.382 & 0.223 & 1 & 0.637 & 1.92 & 0.128 & 28.78 \\
\hline Faktor Produk (X4) & -2.273 & 2.341 & 0.942 & 1 & 0.332 & 0.103 & 0.001 & 10.14 \\
\hline Faktor Pengembang (X5) & -5.029 & 1.859 & 7.318 & 1 & 0.007 & 0.007 & 0 & 0.25 \\
\hline Constant & 32.742 & 9.857 & 11.034 & 1 & 0.001 & $1.65872 \mathrm{E}+14$ & & \\
\hline
\end{tabular}




\subsection{Pembahasan Hasil Analisa Data}

Responden yang membeli apartemen kelas menengah bawah di Surabaya mementingkan lokasi dan PSU namun mengesampingkan kualitas produk. Hal ini dikarenakan konsumen apartemen yang kebanyakan pengusaha, berusia lebih muda dan gemar kuliner ataupun nonton bioskop, sehingga lokasi dianggap penting untuk memperoleh mobilitas tinggi dan akses singkat ke berbagai shopping mall. Sedangkan faktor kualitas bangunan tidak menjadi masalah karena bangunan gedung tinggi memiliki standard kualitas tersendiri dari pemerintah dan kontraktor gedung tinggi memiliki kualifikasi profesi yang lebih khusus. Responden yang membeli rumah kelas menengah bawah di Gresik atau Sidoarjo tidak mengutamakan lokasi tetapi kualitas produk. Faktor kualitas produk menjadi hal yang penting karena jumlah kontraktor rumah tinggal tentu lebih banyak dibanding gedung tinggi, dan kualifikasi atau standardisasinya tidak seketat gedung tinggi. Lokasi bukan menjadi masalah utama karena dengan batasan harga tersebut (dibawah 500 juta rupiah) sangat sulit mendapatkan rumah tinggal di kota Surabaya sehingga tidak ada pilihan lagi selain lari ke pinggiran.

Analisa regresi menunjukkan bahwa ada dua faktor yang paling signifikan yaitu faktor pendidikan konsumen dan faktor pengembang. Pendidikan konsumen apartemen lebih tinggi dengan mayoritas Sarjana dan Pasca-Sarjana sedangkan konsumen rumah mayoritas SMA/SMK. Dari segi faktor pengembang, konsumen apartemen menengah bawah di Surabaya memberi nilai (rata-rata 4.43) lebih tinggi dibanding konsumen rumah menengah bawah di Gresik atau Sidoarjo (rata-rata 3.51) karena karakter konsumen apartemen yang lebi muda, berpendidikan lebih tinggi, beretnis Tionghoa dan bekerja sebagai pengusaha, sehingga kriteria penilaian terhadap pengembang menjadi lebih tinggi. Selain itu mayoritas pembeli apartemen menengah bawah di Surabaya bukan first-home buyer sehingga sangat mungkin pembelian tersebut bertujuan investasi. Penilaian mereka terhadap faktor pengembang tentu lebih tinggi karena investor properti sangat mementingkan rekam jejak pengembang (Khoirudin 2013).

\section{KESIMPULAN DAN SARAN}

\subsection{Kesimpulan}

Ada beberapa perbedaan karakter konsumen pada kedua jenis properti ini. Konsumen apartemen kelas menengah di Surabaya memiliki rata-rata tingkat pendidikan yang lebih tinggi daripada konsumen rumah kelas menengah bawah di Gresik atau Sidoarjo. Selain itu konsumen apartemen tersebut juga cenderung berusia lebih muda, berpenghasilan lebih tinggi, kebanyakkan beretnis Tionghoa, dan bekerja sebagai pengusaha. Sedangkan konsumen rumah kelas menengah bawah di Gresik dan Sidoarjo mayoritas beretnis Jawa dan mayoritas bekerja sebagai karyawan swasta/negeri. Penelitian ini membuktikan bahwa ada perbedaan faktor yang mempengaruhi keputusan pembelian rumah kelas menengah bawah di Gresik dan Sidoarjo dan apartemen kelas menengah bawah di Surabaya yaitu pendidikan terakhir konsumen dan faktor pengembang. Konsumen apartemen menengah bawah di Surabaya memiliki pendidikan lebih tinggi sehingga lebih mementingkan profil dan brandimage pengembang (faktor pengembang).

\subsection{Saran}

Saran-saran untuk pengembang tersebut dapat dijelaskan sebagai berikut:

1. Segmentasi Market: Pengembang dapat memperjelas segmen market yang dituju

2. Keunggulan dan Fitur Produk: Pengembang dapat fokus memperkuat beberapa fitur yang paling mempengaruhi pembelian sesuai dengan karakter konsumennya 
3. Media Periklanan: Pengembang wajib menjalin program dan kerjasama yang baik dengan broker properti karena penjualan melalui broker terbukti efektif

Sedangkan saran untuk penelitian terkait di kemudian hari adalah dengan memperluas faktor independen yang diteliti seperti cara pembayaran, kondisi ekonomi eksternal, dan jenis primary/secondary property. Selain itu batasan kelas sosial dan lokasi properti juga dapat diperlebar seperti kelas atas dan kelas bawah maupun peneletian untuk obyek lokasi properti di kota lain.

\section{DAFTAR PUSTAKA}

Arleflanto, D. T. (2011). "Pengaruh Kualitas Produk dan Kualitas Layanan terhadap Kepuasan Pelanggan Apartemen Metropolis di Surabaya." Unpublished Postgraduate Thesis. Jurusan Manajemen Fakultas Bisnis dan Ekonomika, Universitas Surabaya. Surabaya.

Azwar, S. (2007). Metode Penelitian, Pustaka Pelajar, Yogyakarta.

Binakarya Jaya Abadi. (2015). Annual Report 2015, Binakarya, Jakarta.

Bhattacharya, G., dan Johnson, R. (1996). Statistics - Principles And Methods, third edition, John Wiley and Sons, Wisconsin.

Cheng, F. dan Cheok, J. (2008). "Importance of Branding for Property Developers in Malaysia." Sunway Academic Journal Vol. 5, No. 1, 65-81.

Erawan, A. (2015). "Kelas Menengah Masih Dominasi Pasar Perumahan Jabodetabek." Allproperty Media, Electronic Working Paper, <http://rumah.com> (Maret 23, 2017)

Faqih, M., Putri, D. A., dan Setijanti, P. (2016). "Consumer's Decision Making to Invest on Condominium and Housing at East Surabaya, Indonesia." International Journal of Education and Research Vol. 4, No. 1, 111-122.

Ibrahim, A. (2016). "Bank Indonesia: Kecepatan Menjual Properti di Surabaya Melambat." Perusahaan Umum Lembaga Kantor Berita Nasional Antara, Electronic Working Paper, $<$ http://antarajatim.com> (Februari 16, 2017)

Keputusan Menteri Keuangan (1996), tentang Tata Cara Pembayaran Pajak Penghasilan Nomor: 393/KMK.04/1996. Menteri Keuangan, Jakarta.

Keputusan Menteri Pemukiman dan Prasarana Wilayah (2003), tentang Pengadaan Perumahan dan Permukiman dengan Dukungan Fasilitas Subsidi Perumahan Nomor: $24 / K P T S / M / 2003$. Menteri Pemukiman dan Prasarana Wilayah, Jakarta.

Katili, P., Stiawan, H., dan Nugroho, B. (2016). "Pengaruh Brand Image Dan Event Marketing Terhadap Keputusan Pembelian Rumah." Unpublished Postgraduate Thesis. Fakultas Teknik, Universitas Sultan Ageng Tirtayasa. Banten.

Khoirudin, M. (2013). Trik Membeli Rumah dan Apartemen Untuk Hunian Dan Investasi, Gramedia Pustaka Utama, Jakarta.

Kwanda, T., Rahardjo, J., dan Wibowo, B. R. (2003). "Analisis Kepuasan Penghuni Rumah Sederhana Tipe 36 di Kawasan Sidoarjo Bedasarkan Faktor Kualitas Bangunan, Lokasi, Desain, Sarana dan Prasarana." Dimensi Teknik Arsitektur Vol. 31, No. 2, 124-132.

Kyle, R., Baird, F., dan Spodek, M. (2000). Property Management, Dearborn Real Estate Education, Chicago.

Listyorini, S. (2012). "Analisis Faktor - Faktor Gaya Hidup dan Pengaruhnya Terhadap Pembelian Rumah Sehat Sederhana." Jurnal Administrasi Bisnis Vol. 1, No. 1, 12-24.

Properti Indonesia. (2014). "Tawaran Baru Apartemen Kelas Menengah." Majalah Properti Indonesia, Electronic Working Paper, <http://mpi-update.com> (Maret 21, 2017)

Rahman, A. (2016). "Tergantung Kelas Menengah." Bisnis Indonesia, Electronic Working Paper, <http://koran.bisnis.com> (Maret 23, 2017)

Rusyanto, E. (2016). "Pasar Terbesar Apartemen di Harga Rp 20 Juta/m2." BeritaSatu, Electronic Working Paper, <http://www.beritasatu.com> (Maret 23, 2017)

Salama, A. (2006). "Lifestyle Theories Approach for Affordable Housing Research in Saudi Arabia." Emirates Journal for Engineering Research Vol. 11, No. 1, 67-76. 
Surendra, D. (2016). "Tren Pembangunan Gedung Vertikal Meningkat." Jawapos, Electronic Working Paper, <http:www.jawapos.com> (Maret 21, 2017)

Widiastuti, E. dan Handayani, S. (2013). "Analisis Faktor-Faktor yang Mempengaruhi Keputusan Pembelian Rumah Bersubsidi dengan Menggunakan Analisis Regresi." Prosiding Seminar Nasional Statistika Universitas Diponegoro. Fakultas Ekonomi, Universitas Diponegoro. Semarang. 